\title{
Islamic Investment Behaviour
}

\author{
Imran Tahir ${ }^{*}$ and Mark Brimble ${ }^{* *}$
}

Key words: Islamic Law, Islamic Investment, Muslim Investors

* Ernst and Young

**All correspondence should be addressed to Mark Brimble at the Department of Accounting, Finance and Economics, Griffith Business School, Griffith University, Logan Campus, Qld 4131, Australia, Ph: (07) 3382 1355, E-mail: M.Brimble@griffith.edu.au 


\title{
Islamic Investment Behaviour
}

\begin{abstract}
In the past decade there has been strong growth in Islamic finance and banking across the globe. This has also been coupled with a movement towards the implementation of Islamic law amongst it adherents. This paper uses an experimental design to investigate the investment behaviours of a group of Muslims. Using Islamic law as guidance we argue that investment in shares is permissible in Islam pursuant to five conditions. Furthermore, we find that the Islam does influence investment behaviour, however the degree to which it does this is influenced by the degree of religiosity of the individual. In addition, we find evidence of 'western style' wealth maximisation amongst Muslim investors as well as a desire to consider sustainable investment principles in asset allocations. These findings have implications for investors, financial advisors, and policy makers.
\end{abstract}

Key words: Islamic Law, Islamic Investment, Muslim Investors 


\title{
1.0 Introduction
}

In recent times there has been a growing trend throughout the Muslim world to strive for the implementation of the Islamic law ("shariah”) in every walk of life, including investments. According to Siddiqui (1994, p.xvi) Islam is not simply a religion that signifies submission to the will of God (“Allah”), but is a way of life that prescribes a complete code of conduct for everyday human life in all its spheres and manifestations. Muslims have always been encouraged to engage in business and share in economic prosperity, as is reflected in the following verse from the Muslim Holy book, the Qur'an, in which Allah says:

\begin{abstract}
"And when the prayer is finished, then may you disperse through the land, and seek the bounty of Allah (through trade, business and lawful professions) and celebrate the praises of Allah so that you may prosper” [Surah Al-Juma 62:10]
\end{abstract}

Islam is the world's second largest religion with “forty-six countries having majority Muslim populations and many others containing significant Muslim minorities” (Sarwar, 1989:203). Most Muslims in the West do not conduct their affairs under the Islamic law; rather they use the common law prevalent in the West. Thus, for a Muslim in the West the only way he/she can afford a large investment (e.g. house) is to take a loan based on interest or invest whatever surplus money he/she has in interest-bearing instruments. In Islam interest in all its forms is forbidden. Therefore any financial instrument that has an element of interest in it is forbidden ("haram”) for Muslims. However, the permissibility of investing in shares is now largely agreed in the relevant literature. Vogel and Hayes (1998:7) state that "compared to conventional 
investors, Muslim savers have relatively few acceptable investment contracts to choose from. Most Islamic funds are confined to short-term, low-risk investment mark-up deals with slim profit margins.” Furthermore, the barring of debt financing in the Islamic world would imply that companies in Muslim countries would need to place a high reliance on equity financing to fund their business activities.

The primary motivation for this research paper is to examine the extent to which a sample of Muslim investors comply with these requirements and what they report are the factors that influence their asset allocation decision in an investment experiment. In particular we are interested in the level of risk aversion and return seeking exhibited by Muslim investors relative to non-Muslim investors (i.e. whether the broad risk-return principles of modern portfolio theory apply).

This study is important for several reasons: (1) it is useful to provide the Muslim community and investment managers with information on how they can invest in equity markets; (2) it is useful to understand whether Muslim investors are behaving in accordance with Islamic investing principles; (3) trade is conducted between Western and Islamic countries and it is, therefore, vital for Westerners to understand the beliefs of Muslims in order to enhance trade and goodwill; (4) this is a little researched area in behavioural finance, despite the significant number of Muslims living in 'Western' countries and the growth in Islamic banking.

Briefly, we find variance in the degree to which Muslim investment behaviour is aligned with Islamic culture with the degree of religious adherence being a determining 
factor. Overlaying this however is evidence of wealth maximisation and, in some cases, a desire to consider sustainable investment principles in asset allocations.

The remainder of this paper is structured as follows. In section 2 the sources of Shariah (Islamic) law are described to enable the reader to appreciate Islamic jurisprudence, which is then applied to assess the permissibility of shares under Islamic law. Section 3 examines the method and data, followed by results in section 4 and concluding comments in section 5.

\subsection{The Application of Islamic Law}

This section aims to briefly highlight the sources of Islamic jurisprudence and apply these sources to establish the permissibility of investment in the shares of a company by Muslims. This is important as it provides the basis for further tests in regards to the investment behaviour of Muslims.

\subsection{Sources of Islamic (Shariah) law}

To evaluate whether or not something is permissible in Islam the sources of Islamic law have to be consulted. Consequently, to determine if investing in shares is permissible in Islam it is important to have a thorough understanding of the sources of Islamic law. Hussain (2004, p.28) states that the origins of the Shariah (Islamic law) are the Quran and the Sunnah (primary sources) and the interpretations of the opinions of learned jurists (secondary sources). Moreover, the opinions of jurists are only to be used as supplementary sources of law where the two primary sources are silent on a matter. 